\title{
IAMJ
}

INTERNATIONAL

AYURVEDIC

MEDICAL JOURNAL

\section{AYURVEDA APPROACH IN THE MANAGEMENT OF TRICHOMONAL VAGINITIS WITH SPECIAL REFERENCE TO KAPHAJA YONIVYAPADA - A REVIEW}

\author{
$\underline{\text { Singh Neelam } K^{1}}, \underline{\text { Sengar Alok }}^{2}, \underline{\text { Khuntia Bipin }}^{3}$ \\ ${ }^{1} \mathrm{MD}$ (Ay.) Prasuti Tantra, Research Officer (Ay.), Regional Ayurveda research \\ institute, Gwalior, M.P, CCRAS, Ministry of AYUSH, Govt. of India. \\ ${ }^{2}$ MD (Ay.) Ayurved Samhita, Lecturer, Department of Samhita-Sidhanta, \\ Bundelkhanda Govt. Ayurvedic Medical college, Jhansi, U.P, \\ ${ }^{3} \mathrm{PhD}$. (Ay.), Principal, K.A.T.S Ayurvedic college \& AMP; Hospital Berhampur, \\ Odisha, 1365, C.P Mission compound, Gwalior Road, Jhansi (U.P), 284003
}

Corresponding Author: drsengar.neelam@gmail.com

\section{https://doi.org/10.46607/iamj2209052021}

(Published Online: May 2021)

Open Access

(C) International Ayurvedic Medical Journal, India 2021

Article Received:27/04/2021 - Peer Reviewed:05/05/2021 - Accepted for Publication:06/05/2021

Check for updates

\section{ABSTRACT}

Trichomonal vaginitis is a common sexually transmitted infection that can cause vaginitis, cervicitis and urethritis. Persistent and recurrent infections are frequent in women, potentially due to the lack of routine screening recommendations for this pathogen, chronic nature of some infections and drug resistance. Modern treatment involves the use of systemic and local antibiotics which create a number of inconveniences during their usage. There are few alternative treatment options for persons with a metronidazole allergy or treatment failure. Ayurveda provides many alternatives and can prove a boon to the ailing humanity not only by curing the disease but also by preventing their recurrences. In Ayurvedic texts, various conditions giving rise to white discharge per vaginum had been described. The signs and symptoms of Shleshmala Yonivyapada are more or less similar to Trichomonal vaginitis. In recent decades, numerous efforts have been made to select, extract, and find the mechanism of plant compounds against pathogens of sexually transmitted diseases. In this article, management of Trichomonas vaginitis reviewed through an Ayurvedic text is elaborated in detail. 
Keywords Ayurveda, Kaphaja Yonivyapada, Trichomonal vaginitis, Yonistrava

\section{INTRODUCTION}

Trichomoniasis is one of the most common sexually transmitted infections (STIs) worldwide caused by a protozoaTrichomonasvaginalis. ${ }^{1}$ Trichomonas vaginitis is the most common gynecological disorder. Abnormal vaginal discharges can occur in a number of conditions, including infections and imbalances in vaginal flora or $\mathrm{Ph}$. In one study looking at women presenting to clinic with concerns about vaginal discharge or a foul smell in their vagina, it was found that $34 \%$ had bacterial vaginosis, $23 \%$ had candidiasis, $32 \%$ of patients were found to have sexually transmitted infections due Trichomonal infection. When abnormal discharge associated with vulval itching and burning, it is called vaginitis. ${ }^{2}$

The most significant concern for the gynaecologist during treatment period of Trichomonas vaginitis is high rates of re-infection, chronic and persistent nature of infections, drug resistance and its side effects like nausea, vomiting, metallic taste of mouth, abdominal pain, vulval itching, constipation, rash, swelling of the tongue, dizziness, fatigue, and darkening of the urine. In addition, metronidazole and its metabolites are mutagenic in bacteria and chronic administration induced tumor formation in rats. ${ }^{3}$ There are few alternative treatment options for persons with a metronidazole allergy or treatment failure. It is associated with cervical neoplasia, infertility, Pelvic inflammatory disease (PID), adverse pregnancy outcome, postoperative infection and Trichomonal vaginalis infection increases the risk of HIV transmission in both men and women. ${ }^{4}$ Due to its high prevalence worldwide and the frequency of coinfection with other STIs make trichomoniasis is a compelling public health concern.

In Ayurvedic texts, various conditions giving rise to white discharge per vaginum has been described. The word shwetpradar (Leucorohea) has not appeared in great trios i.e. Charaka, Sushruta and Vagbhata samhitas, commentator Chakrapani, Sharangdhar samhita, Bhavprakash and Yogratnakara have used the word Shwetpradar for white discharge. A complaint of vaginal discharge very much depends upon woman's own perception, power of observation and tolerance etc., or it has great individual variation. All the signs and symptoms of Shleshmala yonivyapada are more or less similar to Trichomonas Vaginitis. ${ }^{5}$

\section{Etiology}

Shwetata (white colouration), coldness, stickiness symptoms are pertaining to Kapha-prakopa (accumulation). ${ }^{6}$ White discharge per vaginum is mainly due to disorders of Kapha. Qualities of kaphadosha are Guru (heavy), Shita (cold), Mridu (soft), Snigdha (unctuous), Madhur (sweet), Sthira (fixed) and Picchila (mucoid/slimy), so the diet agonist to these qualities can vitiate Kapha. ${ }^{7}$

Ailments related with Kaphadosha arises because of seasonal changes, excessive intake of madhur, amla (sour) and lavana (salty) ahar, dairy products, sleeping during day time and lack of exercise. ${ }^{8}$ Rasa dhatu and kaphadosha are in close relation, hence rasa disorders will also result in disorders of Kapha. ${ }^{9}$ Kapha- prakopa is always accompanied with either disorders of vatadosha or pittadosha, it vitiates the Artava-vahasrotas (genital system) and produces the symptoms of Kaphaja Yonivyapad.

\section{Pathogenesis}

Dosha - Vata and kapha, Dushya - Rasa, Rakta \& mansa, Srotasa - Rasavaha, raktavaha, artavavaha, Srotodustilakshan - Atipravriti, Adhisthan - Yoni, Rogamarga - Abhyantara, Sthanasamsraya Yonimarga and Garbhashaya

\section{Clinical features}

Kapha vitiated due to excessive use of abhisyandi (articles producing oozing or serous effusion) substances reaches reproductive system and causes unctuousness, coldness, itching and dull pain in vagina. The woman looks anemic and discharges yellowish, unctuous menstrual blood is the opinion of Caraka.${ }^{10}$ Cakrapani has equated this with Kaphaj- 
asrgdara on the basis that yellowish discharges per vaginum are present during intermenstrual period also. Susruta has given only local symptoms as presence of unctuousness, itching and excessive coldness. ${ }^{11}$ Both vagbhatas have followed the acharya Caraka, however have included painless and yellowish discoloration of vagina also. ${ }^{12}$ Madhavanidana, Bhavaprakasha and Yogratnakara etc. have followed Susruta. Main characteristic features of this condition are presence of itching in vagina and unctuous discharges, which has a resemblance with trichomonal vaginitis.

\section{Material and methods}

All the relevant literatures including classical Ayurvedic texts with their commentaries and recent modern literature, journal, their electronic data base including Google scholar, PubMed, were referred and reviewed. Literature related to the title was explored, rationality and evidence were studied, and conclusion has been drawn.

\section{Observation}

A vaginal discharge varies in its characteristics according to the dosha-dushti at its base. If one takes into consideration the type of discharge, whether it is tanu(watery),picchil, styana (thick/collected into mass) avila-tantula (mucopurulent) or durgandhi pita (offensive yellowish),it is easy to understand the underlying pathology. Styana, avila-tantula and durgandhi pita discharges denotes the Kaphaprakopa in a stage of samawastha. When Kaphaprakopa especially of its pichchil and snigdha accompanied with vataprakopa of its chala guna this picchil type of discharges occurs. (Table 1).

Table 1: Doshic involvement in various type of vaginal discharges ${ }^{[13]}$

\begin{tabular}{|l|l|}
\hline Type of discharges & Dosha involvement \\
\hline Tanu (watery) & Kapha, pitta(dravaguna) \\
\hline Pichchila (Mucoid) & Kapha(pichchila\&snigdhaguna), Vata(chalaguna) \\
\hline Styana (Thick curdy) & Kapha(sama) \\
\hline Avila- Tantula (Muco-purulent) & Kapha(sama), vata \\
\hline PeetaDurgandhi(purulent) & Kapha(sama), pitta \\
\hline
\end{tabular}

Table 2: Differentiation of condition by examining the discharge. ${ }^{[14]}$

\begin{tabular}{|l|l|l|l|l|}
\hline Tanu (watery) & $\begin{array}{l}\text { Pichchila } \\
\text { (Mucoid) }\end{array}$ & Styana (Thick curdy) & Avila- Tantula (Muco-purulent) & $\begin{array}{l}\text { PeetaDurgandhi } \\
\text { (purulent) }\end{array}$ \\
\hline Soma roga & $\begin{array}{l}\text { Kaphaja } \\
\text { yonivyapada }\end{array}$ & Atyanandayonivyapada & Karniniyonivyapada & Raktagulma \\
\hline Acharnayonivyapada & $\begin{array}{l}\text { Upapluta } \\
\text { yonivyapada }\end{array}$ & Kaphajayonikanda & Yoniarsha (Kaphaja) & Phiranga \\
\hline Kaphajapandu & $\begin{array}{l}\text { Aticharana } \\
\text { yonivyapada }\end{array}$ & & & Upadamsha \\
\hline Rajayakshma & Kaphashotha & & & \\
\hline & Amawata & & & \\
\hline & Krumi & & & \\
\hline & KaphajaPrameha & & & \\
\hline
\end{tabular}

\section{DISCUSSION}

\section{Ayurveda principle and approach}

Vaginal discharge is a symptom found in various diseases. Hence the curative treatment for any type of vaginal discharge is to remove the underlying diseases. The modern science also agrees that treatment of vaginal discharge varies with the cause. Foreign bodies must be removed, infection and neoplasm should be treated accordingly. 
As discharges per vaginum especially white discharge is due to disordered kapha, the main aim would naturally be to bring kapha to normal state. For this various kaphaghna drugs are advised. These drugs should possess ruksha (dry) and usna (hot) qualities. Generally, the drugs used should have an action of decreasing kleda, diminishing kapha and absorbing water. Hence drugs of katu, kasaya tikta rasa are used. ${ }^{15}$ Various Kaphaghna drugs are used internally. While administering Various Kaphaghna drugs, the accompanying dosha-dusti and dhatu-vaishamya must be considered. When vaginal discharge accompanied with pittadushti then arogyavardhini vati, pugakhanda and pushyanuga churna are used and when it is associated with vatadushti and dhatukshaya then pradarantak rasa and pradarilouha will be useful. In the stage of samakapha, Triphala guggul, Lodhrasava and chanderprabha vati are used. ${ }^{16}$ Charak has described the use of Rohitaka moola (Tecoma undulata) kalka (Paste) along with water in shwetpradar. ${ }^{17}$

Kandughna mahakasaya (Anti- pruritic medicines) e.g. Manjishtha (Rubia cardifolia), Haridrac (Curcuma longa), Daruharidra (Berberis aristata) and Karanj (Pongamia pinnata) possess Laghu, Ushna, Rooksha and Lekhan properties. They decreased the kapha and removes kleda which is main factor in Itching. Some medicines do cleanse and pacifying vitiated blood, which is the cause of Itching eg. Chandan (Santalum album), Nimba (Azadirachta indica), Usheer (Vetiveria zizanioides) and Kutaja (Holarrhena antidysenterica). ${ }^{18}$ These mahakasaya are useful in kaphaj and uppluta yonivyapada, yonikandu (vaginal itching) and in shwetpradar. Vasti of cow urine mixed with the drugs having predominantly katu rasa and katu vipaka properties should be given. ${ }^{19}$

\section{Importance of Sthanik-Chikitsha (Local Treatment)}

Varti (pessary/vaginal tablets), pichu (vaginal tampoon) and kalka (paste) kalpana are employed for local action of drug. The various drugs used have healing, astringent and hygroscopic action. Selection of drugs depends on the type of strava (Vaginal discharge), accompanying symptoms and pathology behind the condition.

The pessaries prepared with the following drugs should be placed in the vaginal canal for the treatment of yonirogas caused by vitiation of shlesma. Local vaginal application of paste of shyama (Operculina Turpethum) should be given. A pessary prepared with powdered yava (barley) or masha (a kind of bean) mixed with rock salt and pesteled with latex of arka (Calatropis procera) should be placed either repeatedly or for a short time and should follow the irrigation of vaginal canal with lukewarm water.A vaginal pessary thick like index finger prepared with pipali (Piper longum), marich (Piper nigrum), masha, satahwa (Anethum graveolens), kustha (Saussurea lappa) and rock salt. ${ }^{20}$ Vaginal tamponing with Dhatkyadi oil ${ }^{21}$ or udumbaradi oil will be useful. ${ }^{22}$ Madhusaindhava pottali is useful in styana strava. Karanja oil pichoo will be useful in severe itching.

In styana and pichchil strava vaginal douching with triphala decoction or satala decoction is useful. Saurashtrijala (Alum) or dashmool decoction or triphala decoction are useful in avila-tantula strava, while Chandan decoction or lodhra (symplocusracemosa) decoction used in durgandhistrava. ${ }^{23}$

Dhoom-chikitsa is used as a measure for local action. Dhoom-chikitsa has srotoshodhana (clears off passage), kledghna, kaphaghna (absorbs secretions) and rakshoghna (Bactericidal and Antiseptic) actions. It is used in all cases of styana and pichchil strava. ${ }^{24}$ Commonly used drugs for medicinal fumigation are dhattur-patra, ajamoda, shatapushpa, haridra and guggul.

Vaginal discharges are mainly due to Kaphadosha, so methods like dhooma, kshara and agnikarma are also used to treat vaginal discharges. ${ }^{25}$

Anti-Trichomonasvaginalis herbs/agents in Ayurveda

Curcumin- In vitro study conducted in 2000 showed that 21 synthetic monocarbonyl analogues of curcumin, untreated trophozoites, and metronidazole at $100 \mu \mathrm{M}$, exhibited anti-T. vaginalis activity 
comparable to metronidazole (no significant statistical difference). It was observed that three curcumin analogues (3a, 3e, and 5e) possess chemical features of interest which can be explored further as alternatives for the treatment of trichomoniasis. ${ }^{26}$

Bola (Myrrh) and Dadima (Punicagranatum)study conducted in 2011, in 33 metronidazoleresistant $T$. vaginalis females which were treated with a combined course of metronidazole and tinidazole. Those still resistant to the combined treatment were given C. molmol. Oleo-resin extract derived from Myrrh, Commiphoramolmol (Mirazid) was given as two capsules $(600 \mathrm{mg}$ ) for six to eight successive days on an empty stomach two hours before breakfast. All patients were seen immediately after treatment completion and again 4 to 6 week later. Also, the plant extract purified from pomegranate (Punicagranatum) was in-vitro investigated for its efficacy against $T$. vaginalis on Diamond media. Extract was tested at different concentrations, diluted with sterile normal saline against cultured $T$. vaginalis. The anti-T. vaginalis activity of $P$. granatum and $C$. molmol showed promising results indicating to the sources of new anti-Trichomonas agents. ${ }^{27}$

Peppermint (Mentha crispa)- Another Double blind randomized controlled clinical trial conducted in 2012, in this study total sixty female patient were randomized in treatment group, M.crispa $(24 \mathrm{mg}$ as single dose) and in control group, Secnidazole (2 gm single dose). After treatment no difference in the proportion of patients was found between groups, adverse effects were significantly higher in Secnidazole group. It concluded that M.crispa is effective and safe alternative for the treatment of trichomonas vaginitis in women. ${ }^{28}$

\section{Garlic (Allium sativum )and Hinga} (Ferulaasafoetida) - study conducted in 2016, showed the Hydroalcoholic extract of Ferula assafoetida at concentration of $0.5,1$ and $2 \mathrm{mg} / \mathrm{ml}$ killed $90 \%$ of the parasites in first hour of exposure and garlic extract at concentration of $0.1 \mathrm{mg} / \mathrm{ml}$ killed $95 \%$ of parasites after 2 hours. Moreover, garlic extract killed $90 \%$ of parasites at concentration of $0.05,0.025$ and $0.0125 \mathrm{mg} / \mathrm{ml}$ after 24 hours of exposure even at low concentration. This study concluded that garlic and ferula asafoetida have significant effect on Trichomonasvaginalis. 0.1 $\mathrm{mg} / \mathrm{mL}$ of $A$. sativum extract caused destruction of $95 \%$ of $T$. vaginalis number in test tube after two-hour exposure with $T$. vaginalis. ${ }^{29}$

Ginger (Zingiber Officinale) - another in vitro study conducted in 2016 to determine the effect of different concentrations of the ginger ethanol extract on the growth of T.vaginalis trophozoites. Three $T$. vaginalisisolates were cultured in a TYI-S-33 medium. The effect of ginger ethanol extracts and its toxicity in different concentrations $(25,50,100,200$, $400,800 \mu \mathrm{g} / \mathrm{ml})$ on mouse macrophages were measured in triplicate exam by MTT [3-(4,5dimethylthiazol-2-yl)-2,5-diphenyltetrazolium

bromide] assay. The effect of ginger on apoptosis induction was determined by Flow cytometry. Study concluded that ginger Ethanol extract induces programmed death in $T$. vaginalis. It is recommended that due to the known teratogenic effect of metronidazole, ginger can be considered as an alternative drug for metronidazole. The disturbance in parasite due to the anti-parasitic activity of gingerol, shogaol, and hexahydro-curcumin, a constituent isolated from the roots of ginger which may have a direct effect on the vitality and viability of parasite. ${ }^{30}$

Chandrashura (Nigellasativa)- Study in 2016 evaluated in vitro clinical efficacy of aqueous and alcoholic extracts as well as seeds oil of nigella sativa on the cultivated $T$. vaginalis trophozoites. Its effect on growth was compared with metronidazole under the same conditions. On comparison both the alcoholic extract and oil proved as efficient as metronidazole in treating $\mathrm{T}$. vaginalis infection. The remarkable effect may be due to its essential oil (omega 3, 6, $9 \& 7$ fatty acids) present in the seed. ${ }^{31}$

\section{Alkaloids}

Several alkaloids, e.g., berberine, dibenzofurans, anthraquinones, polyacetylenes, saponins, and diterpenes have been analyzed as an alternative effective against $T$. vaginalis. ${ }^{32}$ 


\section{CONCLUSION}

This paper concludes that, as till today, re-infection and drug resistance is most common challenge faced by gynecologist during treatment period of Trichomonal Vaginitis. This challenge can be easily overcome through Ayurveda. Trichomonal Vaginitis can be managed effectively with an Ayurvedic approach and its recurrences can be well prevented through Ayurveda.

\section{REFERENCES}

1. Van der Pol B. Trichomonasvaginalis infection the most prevalent nonviral sexually transmitted infection receives the least public health attention. Clin Infect Dis. 2007; 44(1):23-25.

2. E. S. Pavid. Genitournary infection and sexually transmitted diseases. In: S. B. Jonathan, editors. Berek and Nork's Textbook of Gynaecoloy. 14 $4^{\text {th }}$ ed. p. Lippincott Williams \& Wilkins, Philadelphia, USA; 2007. pp.544

3. M. Mueller, J. G. Meingassner, W. A. Miller, and W. J. Ledger, "Three metronidazole-resistant strains of Trichomonasvaginalis from the United States," American Journal of Obstetrics and Gynecology, vol. 138, no. 7, pp. 808-812, 1980.

4. Soper D. Trichomoniasis: under control or undercontrolled?. Am J Obstet Gynecol. 2004 Jan. 190(1):281-90.

5. Prof $(\mathrm{Km}) \mathrm{P}$. V. Tewari, Prasutitantra and striroga, Part 2, Reprint ed., Chaukhambha Orientalia Varanasi,2005: 266-268.

6. 6.Agnivesh, Charak Samhita, Sutrasthana, Maharoga Adhyaya 20/18, Brahmanand Tripathi editor, Reprint ed. Chaukhamba Surbharti Prakashana, Varanasi, 2002; 244

7. Vagbhata, Asthang Hridya, Sutrasthana, Doshabhediya Adhyaya 12/53, Atrideva Gupta editor, Seventh ed., Chaukhamba Sanskrita Sansthan Varanasi, 1980:94

8. Sushruta, Sushruta Samhita, Sutrasthana, Vranaprashana Adhyaya 21/23, G.D. Singhal editor, Second ed., Chaukhamba Sanskrita Pratisthan Delhi, 2007:196

9. Ibidem, Asthang Hridya (7), Sutrasthana, Doshadivigyaniya Adhyaya 11/26;88

10. Agnivesh, Charaka Samhita, Chikitsasthana, Yonivyapadachikitsa Adhyaya, Vol 5, 30/13-14.
Sharma RK, Dash B editors, Reprint ed., Chowkhamba Sanskrit Series Office Varanasi, 2015:132

11. Ibidem, Sushruta Samhita (8), Vol.9, Uttartantra, Yonivyapadapratishedha Adhyaya38/17;267

12. Ibidem, Asthang Hridya (7), Uttartsthana, Guhyarogavigyaniya Adhyaya 33/44;569

13. Nirmala G. Joshi: Ayurvedic concepts in Gynaecology. $2^{\text {nd }}$ ed. Chaukhambha Sanskrit Pratisthan Varanasi, 2000:123

14. Ibidem, Ayurvedic concepts in Gynaecology (13), Vaginal discharges 9;124

15. Ibidem, Asthang Hridya (7), Sutrasthana, Doshabhediya Adhyaya 12/21;91

16. Ibidem, Ayurvedic concepts in Gynaecology (13), Vaginal discharges 9;126

17. Ibidem, Charaka Samhita (10), Chikitsasthana, Yonivyapadachikitsa Adhyaya, Vol 5, 30/116-117;159

18. Ibidem, Charaka Samhita (6), Sutrasthana, shadavirechanashatasritiya Adhyaya, 4/14;53

19. Ibidem, Charaka Samhita (10), Chikitsasthana, Yonivyapadachikitsa Adhyaya, Vol 5, 30/85;151

20. Ibidem, Charaka Samhita (10), Chikitsasthana, Yonivyapadachikitsa Adhyaya, Vol 5, 30/70;148

21. Ibidem, Charaka Samhita (10), Chikitsasthana, Yonivyapadachikitsa Adhyaya, Vol 5, 30/78-81;150

22. Ibidem, Charaka Samhita (10), Chikitsasthana, Yonivyapadachikitsa Adhyaya, Vol 5, 30/73-78;149

23. Ibidem, Ayurvedic concepts in Gynaecology (13), Vaginal discharges 9;127

24. Ibidem, Asthang Hridya (7), Sutrasthana, Doshaupkramaniya Adhyaya 13/12;97

25. Ibidem, Sushruta Samhita (8), Sutrasthana, ksharpakavidhi Adhyaya11/5;86

26. Carapina DS, Caroline P, Bruna S; Das N, Raquel $\mathrm{N}$; Dié A, et al. Antiparasitic activity of synthetic curcuminmonocarbonyl analogues against Trichomonasvaginalis. Biomedicine \& pharmacotherapy Biomedecine \& pharmacotherapie. 2000; 111:367-377

27. G M El-Sherbiny, E T el Sherbiny. The effect of commiphoramolmol (myrrh) in treatment of trichomoniasisvaginalis infection. Iran Red Crescent Med J 2011; 13(7):480-48630.

28. Moraes ME, et al. Efficacy of menthe crispa in the treatment of women with trichomonasvaginalis infection. Arch Gynecol Obstet2012;286(1):125-30

29. Sarkari b.*, Tadayon h., Askarian sh., Farnia e., Askarianm. In vitro anti-trichomonas activity of freulaassafoetida and garlic extracts. $\underline{J}$ of gorgan 
university of medical sciences fall $2009 ; 11(31): 13-$ 17.

30. Mohsen A., Mahdi D, Zohre F.K.., Mohsen T., Hossein H. Ginger (Zingiberofficinale) induces apoptosis in Trichomonasvaginalis in vitro. Int J Reprod Bio Med 2016;14(11): 691-698

31. Mona A. A., Mahmoud H.A.K. A., Hanan A. H Are the fatty acids responsible for the higher effect of oil and alcoholic extract of Nigella sativa over its aqueous extract on Trichomonasvaginalistrophozoites? J Parasit Dis 2016; 40(1):22-31

32. Gehrig, S.; Efferth, T. Development of drug resistance in Trichomonas vaginalis and its overcoming with natural products. Open Bioact. Comp. J. 2009, 2, 2128.

\section{Source of Support: Nil}

\section{Conflict of Interest: None Declared}

How to cite this URL: Neelam Singh et al: Ayurveda Approach In The Management Of Trichomonal Vaginitis With Special Reference To Kaphaja Yonivyapada - A Re-view. International Ayurvedic Medical Journal \{online\} 2021 \{cited May, 2021\} Available from: http://www.iamj.in/posts/images/upload/1076 1082.pdf 